\title{
TIPIKAL KUANTITAS INFILTRASI MENURUT KARAKTERISTIK LAHAN (KAJIAN EMPIRIK DI DAS CIMANUK BAGIAN HULU)
}

\author{
Dede Rohmat \\ Jurusan Pendidikan Geografi FPIPS UPI \\ Jl. Dr. Setyabudhi No. 229 Bandung 40154, Telp. 0811210716/08156415481 \\ E-mail: rohmat_dede@yahoo.com
}

\begin{abstract}
Rate of infiltrate can be conduct as function of permeability, suction head and moisture of soil parameter. The parameters have close relationship with soil physical characteristics. That relation can be formulated by empirical research. This study have aim to get typical infiltrate quantity based on land characteristics. Method of Green-Ampt infiltrate developed and used to study typically of infiltrate capacity on Upstream of Watershed (Case on Upstream Cimanuk Watershed). Research conducted use empirical and analytical approach.Study conducted at Oxisol Soil occupied by five kinds of land use. There are 96 soil samples was gathered, taken away from 16 observation points. About 12 parameters of soil physical properties were analyzed to each soil sample. The study covering, development of typical capacities infiltrate pursuant on empiric data at multifarious land characteristics (forest; agro forestry; second crops (palawija); settlement; and non arable land). The precipitation intensity has been formulated as function of rainy duration and its probabilities. $K$ formulated as function of volumetric water content; rapid drainage pores, and slow drainage pores $(K=f(\theta, \eta, \eta)$. Parameter of $y$, formulated as function of soil moisture $(\psi=f(\theta))$. Parameter of $F(T)_{\text {dunm }}$, formulated as function of $p$ and $t ;($ $\left.F(T)_{\text {Dummy }}=F(t, p)\right)$. So that pursuant to empirical data, rate of infiltrate $\left.f(t)\right)$ of Green Ampt developed as $f\left(t=f\left(\theta, \eta_{i}, \eta_{p} \tau, \pi\right)\right.$; and infiltrate cumulative can be calculated by $F(F=f(t)$, t). Infiltrate of every kinds of land characteristics have pattern which much the same to, but differ in its quantity.
\end{abstract}

Keywords: infiltrate typical, infiltrate, bydraulic conductivity, soil physis, suction head, watershed

\section{PENDAHULUAN}

Pembentukan dan perluasan lahan kritis sangat berkaitan dengan proses erosi. Daerah Aliran Sungai (DAS) bagian hulu, faktor aliran permukaan (surface run off) merupakan faktor utama penyebab erosi. Tingkat kerusakan lahan akibat erosi sangat ditentukan oleh besar kecilnya aliran permukaan, sedangkan aliran permukaan sangat dipengaruhi oleh curah hujan, infiltrasi, intersepsi, evapotranspirasi, dan storage.

Jika evapotranspirasi selama kejadian hujan diasumsikan sama dengan nol; intersepsi dan storage diasumsikan mempunyai batas optimum yang akan dicapai oleh besar hujan tertentu, maka aliran permukaan merupakan fungsi dari infiltrasi. Infiltrasi sangat bergantung atas sifat fisik dan hidraulik kolom tanah, 
penggunaan lahan, kondisi permukaan tanah, dan faktor eksternal hujan.

Metode infiltrasi Green-Ampt merupakan metode pendugaan kapasitas dan laju infiltrasi. Metode ini metode lama, namun hingga sekarang masih tetap digunakan karena hasil pendugaannya tidak lebih buruk dari hasil pendugaan metode pendugaan infiltrasi yang lebih baru. Selain itu, metode Green-Ampt menarik banyak perhatian, karena metodenya sederhana, didasarkan atas karakteristik fisik, dan parameternya dapat diukur.

Laju infiltrasi menurut Green-Ampt (1911), merupakan fungsi dari parameter hidraulik tanah. Yaitu permeabilitas, suction head, dan kelembaban tanah. Parameter-parameter tersebut mempunyai hubungan erat dengan karakteristik fisik tanah. Hubungan antara dua karakteristik tanah tersebut dapat diformulasikan melalui penelitian empirik.

\section{Metode Green-Ampt}

Green dan Ampt mengembangkan pendekatan Teori Fisik yang dapat diselesaikan dengan Penyelesaian Analitik Exact (Exact Analytical Solution) untuk menentukan infiltrasi (1). Infiltrasi adalah penetrasi air dari permukaan ke dalam tanah secara vertikal.

Dalam Pendekatan ini, Green Ampt mengemukakan istilah Front Pembasahan, yaitu suatu batas yang jelas antara tanah yang mempunyai kelembaban tertentu (q) di bawah dengan tanah jenuh (h) di atasnya. Front pembasahan ini terdapat pada kedalaman L yang dicapai pada waktu t dari permukaan (Gambar 1).

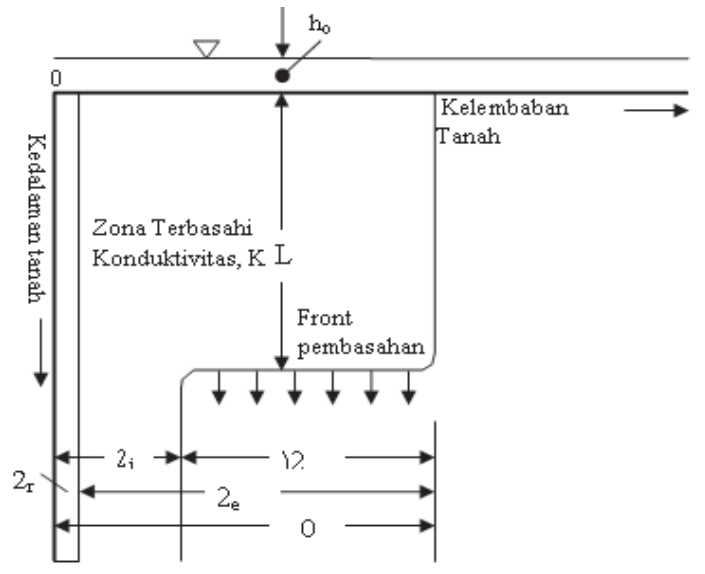

Sumber: Chow, 1989; 108

Gambar 1. Zonasi Kelembaban Tanah Akibat Infiltrasi

Dalam pendekatan ini, kontrol volume kolom tanah digunakan sebagai satuan analisis. Kontrol volume merupakan satuan analisis yang dibatasi oleh luas permukaan dan kedalaman L. Air yang masuk ke dalam akan menyebabkan pertambahan kelembaban tanah dari kelembaban awal (q) pada kedalaman (L), maksimum menjadi porositas (h).

Pertambahan air sebagai hasil infiltrasi untuk suatu unit volume adalah $\mathrm{L}(\eta-\theta)$ atau sama dengan infiltrasi kumulatif (F) (Gambar 2):

$$
\begin{aligned}
\mathrm{F} & =\mathrm{L}(\mathrm{h}-\mathrm{q}) \\
& =\mathrm{L} \mathrm{Dq} \ldots
\end{aligned}
$$

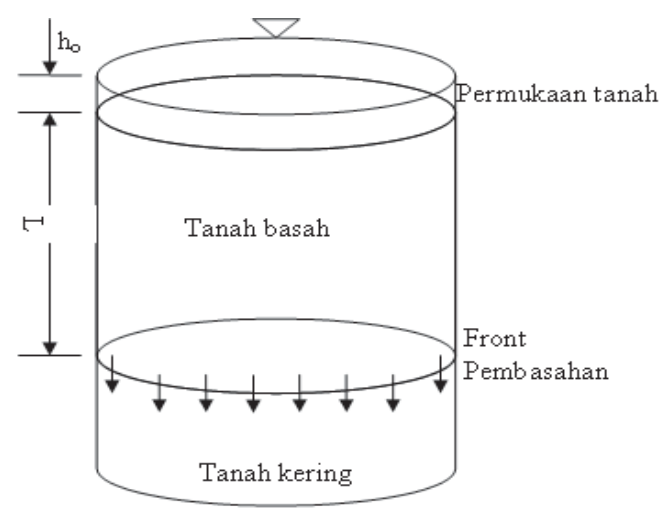

Sumber: Chow, 1989; 112

Gambar 2. Infiltrasi Kolom Tanah 
Hukum Darcy's menyajikan persamaan momentum untuk suatu flux, yaitu :

$$
\mathrm{q}=-\mathrm{K} \frac{\partial \mathrm{h}}{\partial \mathrm{z}}
$$

Nilai q (Darcy flux) untuk seluruh kedalaman adalah konstan; didekati oleh - f:

$$
\mathrm{q}=\mathrm{K} \frac{\left(\mathrm{h}_{1}-\mathrm{h}_{2}\right)}{\left(\mathrm{z}_{1}-\mathrm{z}_{2}\right)}
$$

Jika $\Psi$ adalah suction head tanah untuk wetting front, $\mathrm{h}_{1}$ adalah head permukaan sama dengan kedalaman genangan $\left(h_{o}\right)$, dan $h_{2}$ adalah head tanah yang kering di bawah wetting front. Head (h) adalah penjumlahan suction head $(\mathrm{Y})$ dan gravity head $(\mathrm{z})$, maka:

$$
\mathrm{h}_{2}=-\Psi-\mathrm{L} \text {. }
$$

Hukum Darcy untuk sistem ini adalah

$$
\begin{aligned}
& \mathrm{f}=\mathrm{K}\left[\frac{\mathrm{h}_{\mathrm{o}}-(-\psi-\mathrm{L})}{\mathrm{L}}\right] \\
& f \approx K\left[\frac{\psi+L}{L}\right]
\end{aligned}
$$

Persamaan di atas untuk asumsi bahwa genangan permukaan $h_{0}$ dapat diabaikan dibandingkan dengan $\Psi$ dan L. Jika ho tidak diabaikan, dapat diasumsikan bahwa $h_{0}=0$. Persamaan 5, disubstitusikan ke dalam persamaan 4:

$$
L=\frac{F}{\Delta \theta}
$$

diperoleh:

$$
f=K\left[\frac{\psi \Delta \theta+F}{F}\right]
$$

Pada saat $f=d F / d t$, persamaan 6 , merupakan persamaan untuk menyatakan tingkat infiltrasi potensial (1). Persamaan 6 dapat diekspresikan sebagai persamaan diferensial dalam $(\mathrm{F})$ yang tidak diketahui.

$$
\frac{d F}{d t}=K\left[\frac{\psi \Delta \theta+F}{F}\right]
$$

sehingga diperoleh integrasinya:

$$
F(t)=\Psi \Delta \theta \ln \left(1+\frac{F(t)}{\psi \Delta \theta}\right)+K t
$$

dimana,

$\mathrm{F}(\mathrm{t})=$ infiltrasi kumulatif

$\Psi=$ suction head

$\Delta \theta=$ selisih antara porositas (h) dengan kandungan air awal (q)

$\mathrm{K}=$ permeabilitas tanah

Persamaan 8, merupakan persama-an Green-Ampt, untuk menghitung infiltrasi kumulatif $\mathrm{F}$ potensial, sedangkan tingkat infiltrasi diperoleh dari:

$$
f(t)=K\left[\frac{\psi \Delta \theta}{F(t)}+1\right]
$$

\section{Karakteristik Fisik Lokasi Penelitian}

Penelitian dilaksanakan di Kecamatan Malangbong Kabupaten Garut Propinsi Jawa Barat, Indonesia (108 14' 08" BT$108^{\circ} 16^{\prime \prime}$ BT dan $06^{\circ} 54^{\circ} 44^{\prime \prime}$ LS - 07 01' 36" LS). Sekitar 7 jam perjalanan darat dari ibu kota Indonesia, Jakarta atau 2 jam dari ibu kota propinsi Jawa Barat, Bandung (Gambar 3).

Lokasi penelitian terletak pada ketinggian 560 - 800 meter di atas permukaan laut (m dpl). Kemiringan lereng berkisar antara 15\% - >40\%. Ratarata hujan tahunan wilayah Cekungan Kecil Cikumutuk sekitar $2.676 \mathrm{~mm}$ per tahun.

Secara geologi, batuan daerah penelitian merupa-kan hasil erupsi gunung api tua yang diperkirakan terjadi pada zaman plio-plestosen, umumnya terdiri dari perselingan breksi, lava, tufa dan lahar bersusunan andesit sampai basal (26).

Menurut Sistem Taksonomi, tanah di lokasi termasuk Great Group Oxorthox, Haplorthox, Rodorthox, dan Chromorthox (11) atau Latosol oksic, Latosol haplik, Latosol rodik, dan Latosol kromik (2). Tanah- 


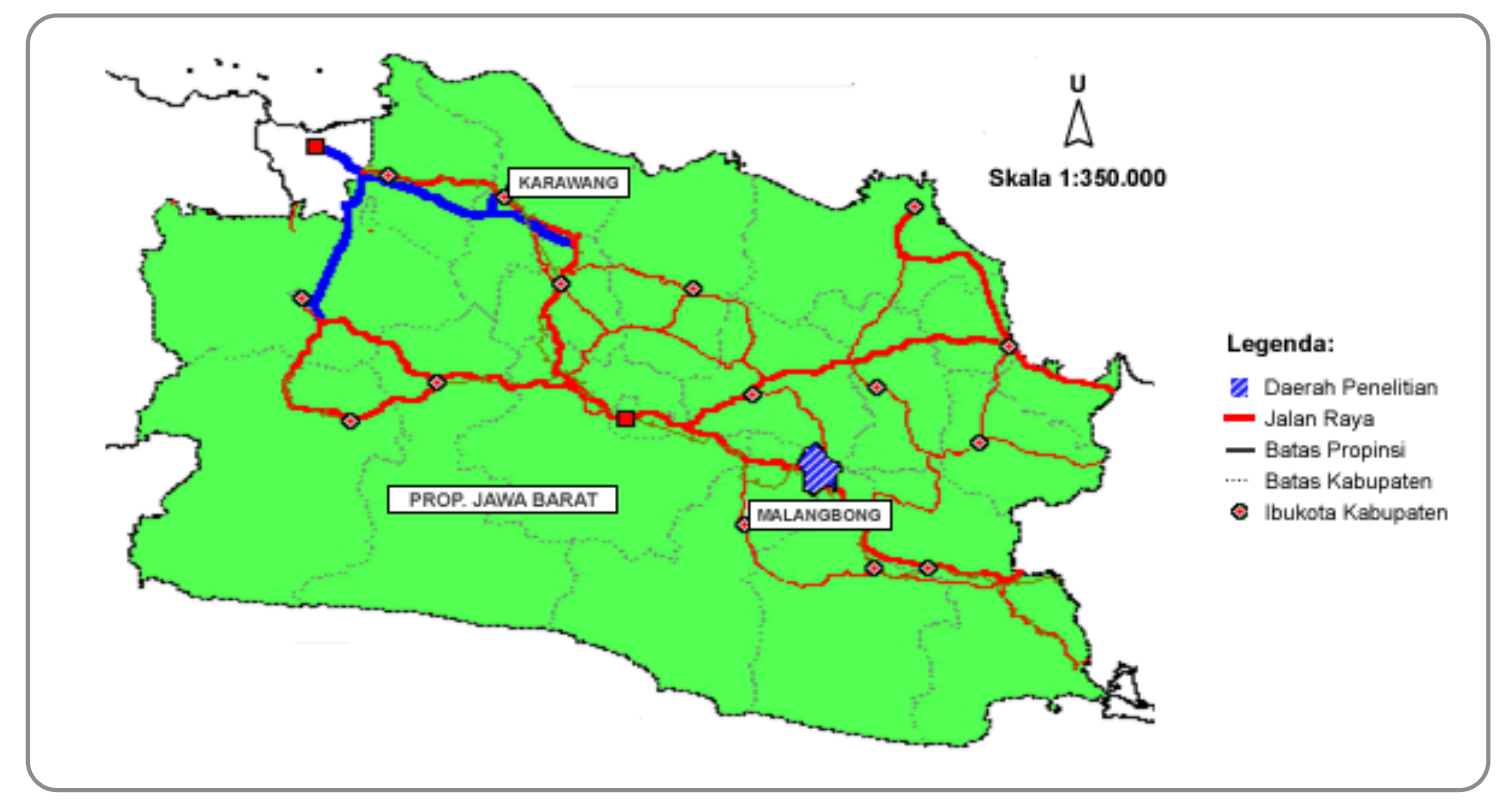

Sumber: Peta Rupa Bumi Indonesia (RBI) Skala 1: 25.000

Gambar 3. Letak Lokasi Penelitian

tanah ini mempunyai tekstur clay loam di permukaan dan clay di bawah permukaan.

Lima macam penggunaan lahan dari tanah tersebut yaitu palawija (second crops), agroforestri (agroforestry), lahan tidak digarap (non arable land), hutan atau kayu campuran (forest or mix timbres) dan permukiman (settlement).

Palawija merupakan budidaya lahan kering dengan dominasi tanaman semusim. Adapun tanaman tahunan difungsikan sebagai tanaman pelindung atau tanaman batas lahan. Jenis tanaman yang ditanam pada lahan ini antara lain jagung, kacang tanah, ubi jalar, padi gogo, singkong, jahe, dan cabe keriting. Palawija tersebar pada tanah Chromorthox, Haplorthox, dan Oxthorthox.

Pengolahan tanah dan pemakaian van organik intensif. Seluruh lahan telah berteras, kemiringan lahan dianggap sama dengan nol. Secara kualitatif, penutupan lahan oleh tajuk tanaman bervariasi dari $50 \%$ sampai dengan $90 \%$.
Agroforestry terdiri atas hutan rakyat dan sistem tumpang sari. Sistem hutan rakyat adalah sistem pemanfaatan lahan dengan tanaman tahunan (100\%). Dominasi tanaman berupa Albazia dari jenis Sengon dan Sengon Buto. Jarak tanam masing-masing sekitar 2 x 3 meter dan 5 x 5 meter. Penutupan lahan mencapai 80 100\%. Pada sistem tumpang sari, tanaman tahunan yang ditemukan adalah cengkih dan sengon, dengan jarak tanam sekitar 10 x 10 meter. Tanaman semusim yang tumbuh di antara tanaman cengkih adalah cabe, sedangkan di antara tanaman sengon adalah jagung dan singkong. Penutupan lahan pada ini sekitar 70\%.

Penggunaan lahan agroforestri tersebar pada tanah Chromorthox, Haplorthox, Oxthorthox, dan Rhodorthox. Lahan umumnya berteras, sehingga kemiringan lereng dianggap sama dengan nol.

Lahan yang tidak digarap, tersebar pada tanah Haplorthox dan Rhodorthox. Tumbuhan dominan adalah semak dari alang-alang dengan penutupan lahan $100 \%$. 
Hutan (kayu campuran) merupakan lahan yang didominasi tanaman tahunan dari jenis kayu-kayuan dan difungsikan sebagai hutan lindung. Di bawah tegakan tumbuh tanaman perdu, semak, dan rumput liar. Dengan demikian, lahan tertutup rapat oleh tajuk tanaman $(100 \%)$. Areal ini menempati tanah Haplorthox dan Chromorthox dengan kemiringan dianggap sama dengan nol.

Permukiman di lokasi penelitian merupakan pemukiman khas upland, berteras, terdapat (tampungan) storage di permukaan lahan, tidak mempunyai saluran drainase khusus, dan mempunyai halaman bermain dan budidaya tanaman pekarangan. Penutupan lahan di areal permukiman sekitar $30 \%-40 \%$. Tanah yang ditempati untuk permukiman adalah tanah Haplorthox, Oxthorthox, dan Rhodorthox.

\section{Prosedur Pengumpulan Data dan Analisis Data}

Penelitian menggunakan metode observasi lapangan, dengan pengedekatan empirik-analitik. Pengamatan lapangan dilakukan dalam kurun waktu 4 bulan, mulai bulan Januari 2001 sampai April 2001.

Rekaman hujan otomatis selama 3 tahun diidentifikasi untuk memperoleh data ketebalan hujan, $(\mathrm{R}(\mathrm{t}))$, durasi hujan (t) dan intensitas hujan setiap kejadian hujan. Data ini digunakan untuk formulasi pola hujan daerah penelitian.

Sampel tanah diambil dari 16 titik pengamatan, representatif pada setiap penggunaan lahan (palawija 5 titik pengamatan; Agroforestry 4 titik pengamatan; non arable land 2 titik sampel; hutan 2 titik sampel; dan permukiman 3 titik sampel).
Sampel tanah yang diambil adalah disturbed soil samples dan undisturbed soil samples. Dua belas buah sampel tanah (6 sampel terganggu dan 6 sampel tidak terganggu), diambil dari setiap titik pengamatan. Masing-masing mewakili kedalaman 0-20 $\mathrm{cm} ; 20-40 \mathrm{~cm} ; 40-60 \mathrm{~cm} ; 60-80 \mathrm{~cm}$; $80-100 \mathrm{~cm}$; dan $100-120 \mathrm{~cm}$. Pengamatan dilakukan satu kali pada awal penelitian.

Analisa laboratorium dilakukan terhadap sampel tanah terganggu untuk mendapatkan nilai variabel coarse sand $\left(\mathrm{s}_{\mathrm{c}}\right.$; $\%)$; fine sand $\left(\mathrm{s}_{\mathrm{f}} ; \%\right)$, silt $\left(\mathrm{s}_{\mathrm{i}} ; \%\right)$; clay $\left(\mathrm{c}_{\mathrm{p}} ; \%\right)$; dan organic matter $\left(\mathrm{O}_{\mathrm{m}} ; \%\right)$. Sampel tanah tidak terganggu dianalisis untuk mendapatkan nilai variable total porosity (h; $\%)$; rapid drainage pores $\left(\mathrm{h}_{\mathrm{c}} ; \%\right)$; slow drainage pores $\left(\mathrm{h}_{\mathrm{p}} ; \%\right)$; bulk density $\left(\mathrm{r}_{\mathrm{b}} ; \mathrm{gr} / \mathrm{cm}^{3}\right)$; particle density $\left(\mathrm{r}_{\mathrm{p}} ; \mathrm{gr} / \mathrm{cm}^{3}\right)$; suction head ( $\mathrm{y}$; $\mathrm{cm})$; potential free energy $(\mathrm{pF})$; volumetric water content (q; \%) (5); dan permeability (K; $\mathrm{cm} / \mathrm{jam})$.

Pengamatan hujan selama kurun waktu penelitian (4 bulan), dilakukan secara otomatis dengan alat yang mampu mengukur waktu hujan, lama hujan, dan ketebalan hujan. Pada kurun ini, infiltrasi kumulatif akibat hujan diukur dari perbedaan kelembaban sampel tanah yang diambil sebelum hujan dan sesudah hujan. Pengambilan sampel tanah dilakukan pada interval kedalaman $20 \mathrm{~cm}$, mulai permukaan tanah hingga kedalaman 120 $\mathrm{cm}$. Kelembaban diukur melalui pengovenan pada suhu $105^{\circ} \mathrm{C}$ selama 10 jam.

Keseluruhan proses penelitian hingga diperoleh hasil akhir model infiltrasi kolom tanah digambarkan dalam bentuk alur proses penelitian (Gambar 4). 


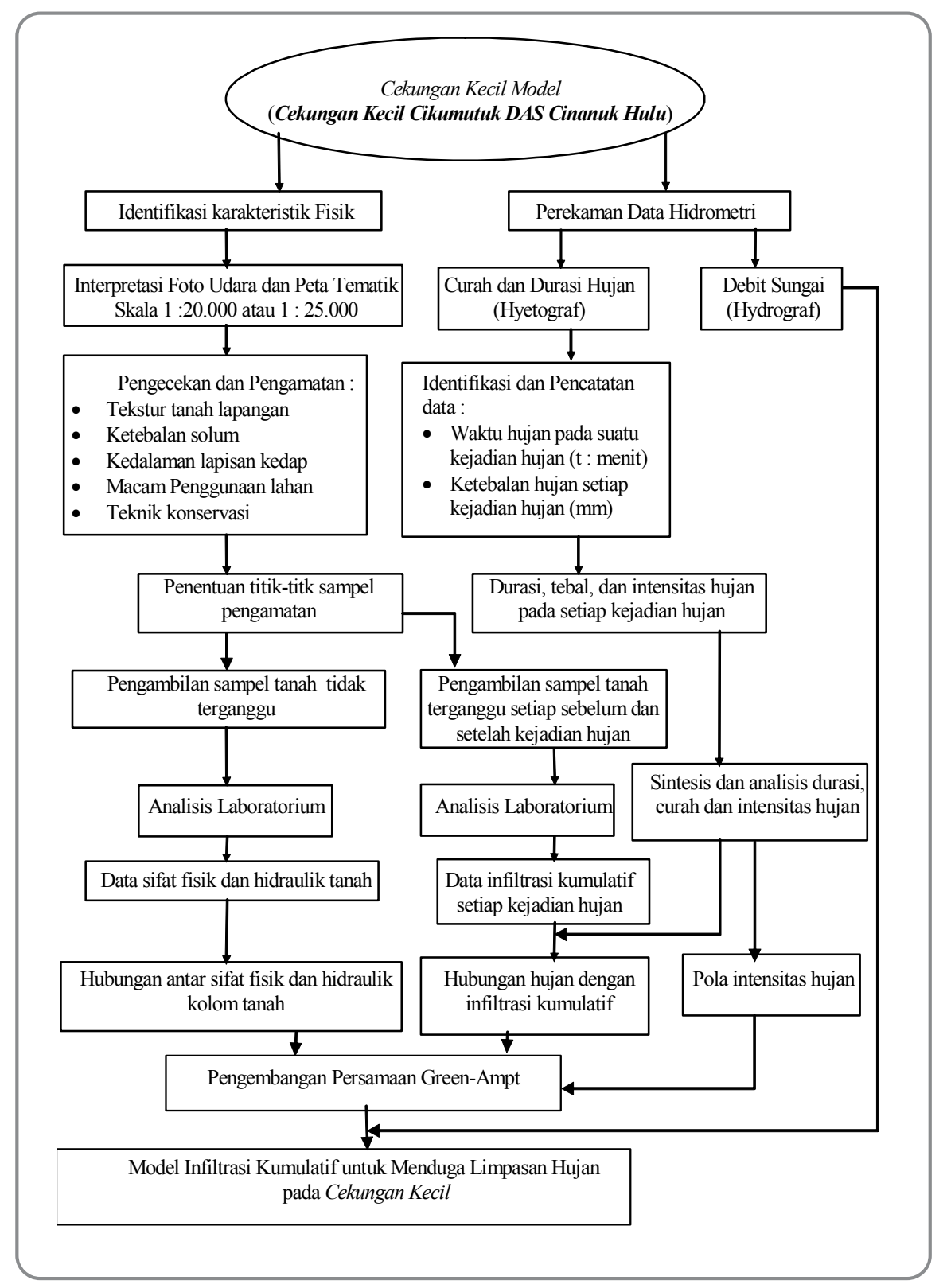

Sumber: Chow, 1998 dengan Modifikasi

Gambar 4. Prosedur Penelitian secara Keseluruhan

\section{HASIL DAN PEMBAHASAN}

\section{a. Sistesis dan Pola Intensitas Hujan}

Pola intensitas hujan diformulasi guna memperoleh pola intensitas hujan yang sesuai dengan wilayah penelitian dan sebagai masukan untuk pengembangan metode pendugaan infiltrasi empirik. Pola intensitas hujan disajikan dalam bentuk persamaan yang menyatakan intensitas hujan (I; mm/jam) sebagai fungsi dari durasi hujan (t; jam) dan probabilitas (\%), atau $I=f(t, p)$. Formulasi dilakukan berdasarkan 162 data kejadian hujan yang direkam selama kurun 3 tahun.

Formulasi pola intensitas hujan dilakukan melalui proses: 
(i) Pengelompokan data hujan menurut durasi hujan $(t=0,25 ; 0,5 ; 1 ; 2 ; 3$; dan 6 jam)

(ii) Transformasi logaritmik data, agar diperoleh data intensitas hujan yang mempunyai sebaran normal.

(iii) Perhitungan probabilitas hujan (p; \%).

(iv) Menghitung pola hubungan antara I dengan p pada setiap kelompok durasi hujan. Hubungan tersebut berbentuk : $\mathrm{I}_{0,25}=10^{(-0,0163 \cdot \mathrm{p}+1,6345)}$

(10)

$$
\mathrm{I}_{0,5}=10^{(-0,0163 \cdot \mathrm{p}+1,4060)}
$$

$$
\mathrm{I}_{1}=10^{(-0,0163 \cdot \mathrm{p}+1,1770)}
$$

$$
\mathrm{I}_{2}=10^{(-0,0163 \cdot \mathrm{p}+1,0760)}
$$

$$
\mathrm{I}_{3}=10^{(-0,0163 \cdot \mathrm{p}+0,9823)}
$$

$$
\mathrm{I}_{6}=10^{(-0,0163 \cdot \mathrm{p}+0,8950)}
$$

(v) Menentukan intensitas hujan berdasarkan sembarang nilai probabilitas untuk setiap kelompok durasi hujan.

(vi) Menentukan pola hubungan antara intensitas hujan dengan durasi dan probabilitas hujan, atau $\mathrm{I}=\mathrm{f}(\mathrm{t}, \mathrm{p})$. Pola hubungan tersebut berbentuk :

$$
I=6,61 e^{-0,0375 \cdot p}+9,16 e^{-0,0375 \cdot p} \frac{1}{t}
$$

Persamaan akhir pola intensitas hujan yang sesuai untuk areal penelitian adalah :

$$
I_{t, p}=\left(\frac{9,16+6,61 . t}{t}\right) e^{-k}
$$

dengan, I adalah intensitas hujan ( $\mathrm{mm} /$ jam); t adalah durasi hujan (jam); e = 2,718; $\mathrm{k}=0,0375$. p; dan $\mathrm{p}$ adalah probabilitas ( $\%$ ). Ketebalan hujan selama kejadian hujan $\left(\mathrm{R}(\mathrm{t})_{\mathrm{t}, \mathrm{p}}\right)$ dihitung menggunakan rumus:

$$
R(t)_{t, p}=I_{t, p} . t
$$

Dengan persamaan 17 dan 18 dihitung intensitas dan ketebalan hujan untuk $\mathrm{t}=0,25 ; 0,5 ; 1 ; 2 ; 3 ; 4 ; 5$; dan 6 jam. Dalam kelompok probabilitas (p) kejadian hujan $50 \%$; $16 \%$; dan $5 \%$. Nilai probabilitas $50 \%$ adalah nilai rata-rata; probabilitas $16 \%$, adalah nilai rata-rata ditambah standar deviasi; dan probabilitas $5 \%$ adalah nilai ekstrim (Gambar 5).

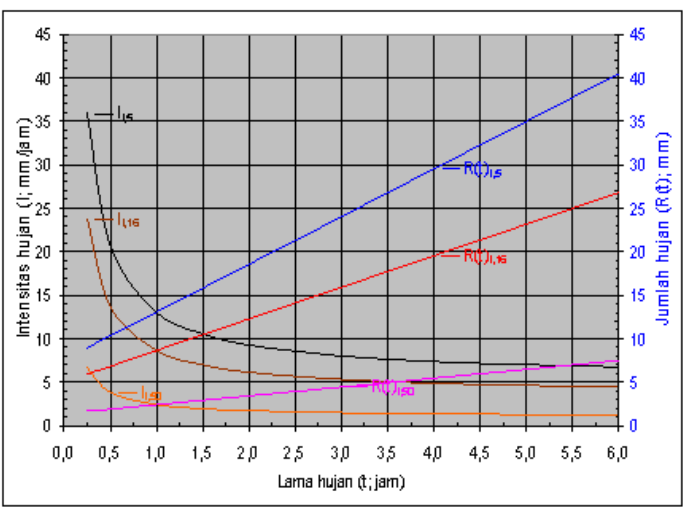

Sumber: Hasil Perhitungan

Gambar 5. Intensitan dan Ketebalan Hujan pada t dan $\mathrm{p}$

\section{b. Pendugaan Suction Head Ber- dasarkan Kelembaban Tanah}

Suction head (y) adalah nilai yang menyatakan energi hisapan tanah terhadap air di dalam pori atau sekitar butir tanah (soil water) (6).

$$
\Psi=-\left(10^{p F}\right)
$$

dengan $\mathrm{pF}$ adalah nilai potensial free energy tanah yang besarnya bergantung pada kandungan air tanah. Dari 96 buah sampel tanah, diperoleh hubungan antara kandungan air tanah (q) dengan nilai $\mathrm{pF}$, yaitu (Gambar 6): 


$$
\begin{aligned}
& \mathrm{pF}=29,30-1,684 \mathrm{q}+0,0371 \mathrm{q}^{2}- \\
& 0,00029 \mathrm{q}^{3}
\end{aligned}
$$

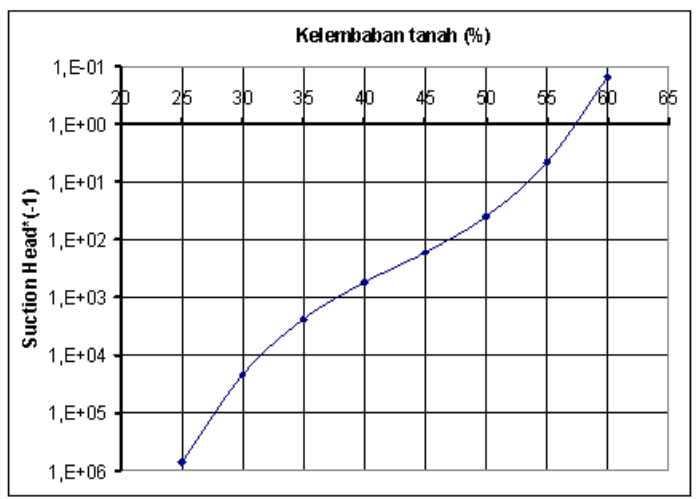

Sumber: Hasil Perhitungan

Gambar 6. Suction Head Versus Kelembaban Tanah

\section{c. Pendugaan Nilai Permeabilitas Berdasarkan Sifat Fisik Tanah}

Permeabilitas menyatakan kemampuan media porus (tanah) untuk meloloskan zat cair (air hujan) baik secara lateral maupun vertical $(\mathrm{cm} / \mathrm{jam})$. Hubungan antara permeabilitas dengan sifat fisik tanah (12 variabel, masing-masing merupakan rata-rata dari 96 buah data) dilakukan dengan analisis regresi linier berganda - metode Backward.

Agar data K tersebar secara normal, data $\mathrm{K}$ ditransformasi menjadi Lon $\mathrm{K}$. Hasil akhir analisis menunjukkan bahwa terdapat tiga variabel sifat fisik tanah yang mempunyai efek signifikan terhadap permeabilitas tanah $(\ln K)$, yaitu kelembaban tanah (q); kandungan pori drainase cepat $\left(\mathrm{h}_{\mathrm{c}}\right)$; dan kandungan pori drainase lambat $\left(h_{\mathrm{p}}\right)$. Sehingga pendugaan permeabilitas $(\mathrm{K})$ dilakukan oleh :

\section{d. Pengembangan Persamaan Tipikal Kuantitas Infiltrasi}

Berdasarkan persamaan 19 dan persamaan 20, persamaan infiltrasi (9) dikembangkan menjadi :

$$
f(t)=10 \cdot e^{a}\left[\frac{\mu}{\chi_{C r}}+1\right]
$$

dengan : $f(t)$ adalah laju infiltrasi (mm/ jam); e adalah Permeabilitas tanah $(\mathrm{cm} /$ jam); $\quad e=2,718 ; \quad a=-2,391-$ $0,090 \cdot \theta+0,161 . \eta_{\mathrm{c}}+0,845 . \eta_{1} ; \mu=\left[-\left(10^{\mathrm{pF}}\right.\right.$. $\Delta \theta)] ; \Delta \theta=\eta-\theta ;$ dan $\chi_{C r}$ adalah infiltrasi kumulatif dummy yang harus dicari formulanya (cm); sedangkan $\mathrm{Cr}$ adalah W (palawija); A (agroforrestri); N (tidak digarap); H (kayu campuran/hutan); (P) permukiman.

Parameter $\chi_{C r}$ dicari dengan pengubahan bentuk persamaan 21 menjadi:

$$
\chi_{C r}=\frac{e^{a}(\mu)}{f(t)-e^{a}}=\frac{e^{a}\left(-\left(10^{p F}\right)\right)(\Delta \theta)}{f(t)-e^{a}} \ldots \ldots .
$$

Parameter $f(t)$ pada persamaan 22, diperoleh dari pembagian infiltrasi kumulatif empirik pada lima macam penggunaan lahan oleh lama hujannya, atau:

$$
f(t)=\frac{F(t)_{C r}}{t}
$$

Berdasarkan hasil pengamatan, nilai parameter $\mathrm{F}(\mathrm{t})_{\mathrm{Cr}}$ mengikuti persamaan :

$$
F(t)_{C r}=10^{K_{C r}}-1
$$

dengan $\mathrm{F}(\mathrm{t})_{\mathrm{Cr}}$ adalah infiltrasi kumulatif empirik $(\mathrm{mm})$ untuk masing-masing macam penggunaan lahan ( $\mathrm{cr}$ ). $\mathrm{K}_{\mathrm{Cr}}$ adalah pola hubungan antara $F(t)$ empirik dengan ketebalan hujannya $(\mathrm{R}(\mathrm{t})$ ) untuk masingmasing macam penggunaan lahan, yaitu : 
$\mathrm{K}_{\mathrm{W}}=-0,0005 \cdot(\mathrm{R}(\mathrm{t}))^{2}+0,045 \cdot \mathrm{R}(\mathrm{t})+0,37$

$\mathrm{K}_{\mathrm{A}}=-0,0005 \cdot(\mathrm{R}(\mathrm{t}))^{2}+0,045 \cdot \mathrm{R}(\mathrm{t})+0,40$

$\mathrm{K}_{\mathrm{N}}=-0,0004 \cdot(\mathrm{R}(\mathrm{t}))^{2}+0,039 \cdot \mathrm{R}(\mathrm{t})+0,38$

$\mathrm{K}_{\mathrm{H}}=-0,0006 \cdot(\mathrm{R}(\mathrm{t}))^{2}+0,050 \cdot \mathrm{R}(\mathrm{t})+0,33$

$\mathrm{K}_{\mathrm{p}}=-0,0004 \cdot(\mathrm{R}(\mathrm{t}))^{2}+0,040 \cdot \mathrm{R}(\mathrm{t})+0,42$

Dengan pola hujan persamaan 18 , dan sifat fisik tanah masing masing penggunaan lahan (Tabel 1), serta infiltrasi kumulatif persamaan 24, parameter $\mathrm{c}_{\mathrm{Cr}}$ penggunaan lahan dapat diprediksi dengan data masukan durasi dan probabilitas hujan, dan sifat fisik tanah (Tabel 1). Infiltrasi kumulatif $\left(\mathrm{F}(\mathrm{t})_{\mathrm{m}}\right)$ dihitung oleh persamaan 25. Hasil prediksi laja infiltrasi dan infiltrasi kumulatif untuk lima macam penggunaan lahan disajikan pada Gambar 7 sampai dengan Gambar 11.

$$
\mathrm{F}(\mathrm{t})_{\mathrm{m}}=\mathrm{f}(\mathrm{t})_{\mathrm{Cr}} \cdot \mathrm{t}
$$

Berdasarkan gambar-gambar tersebut,

Tabel 1. Sifat-Sifat Fisik Tanah di Areal Penelitian

\begin{tabular}{clccccc}
\hline \hline Symbol & Land coverage & $\boldsymbol{\theta}(\mathbf{\%})$ & $\boldsymbol{\eta}_{\mathbf{c}}(\mathbf{\%})$ & $\boldsymbol{\eta}_{\boldsymbol{\lambda}}(\mathbf{\%})$ & $\mathbf{2}(\mathbf{\%})$ & $\boldsymbol{\Delta} \boldsymbol{\theta}$ \\
\hline W & Second crop (palawija) & 60.69 & 13.40 & 5.01 & 42.88 & 0.1781 \\
A & Agroforestry & 60.94 & 14.52 & 5.03 & 41.63 & 0.1931 \\
N & Non-arable & 58.73 & 11.71 & 4.89 & 43.73 & 0.1500 \\
H & Forest & 58.39 & 11.51 & 4.96 & 45.13 & 0.1326 \\
P & Settlement & 58.79 & 11.07 & 4.96 & 45.17 & 0.1362 \\
\hline
\end{tabular}

Sumber: Hasil Analisis Data Primer

untuk masing-masing penggunnaan lahan diformulasikan sebagai :

$\chi_{W}=\frac{69.36}{p^{0.091}} e^{\frac{1.99}{t} p^{-0.59}} ; \chi_{A}=\frac{95.93}{p^{0.077}} e^{\frac{0.77}{t} p^{-0.40}} ;$

$\chi_{N}=\frac{59.48}{p^{0.148}} e^{\frac{2.03}{t} p^{-0.46}} ; \quad \chi_{H}=\frac{61.58}{p^{0.268}} e^{\frac{4.95}{t} p^{-0.75}} ;$

dan $\chi_{P}=\frac{57.46}{p^{0.251}} e^{\frac{5.72}{t} p^{-0.66}}$

Pada setiap probabilitas, semua $\chi_{\mathrm{Cr}}$ sebagai fungsi dari durasi hujan membentuk garis linier pada grafik semilogaritmik.

\section{e. Tipikal Kuantitas Infiltrasi}

Berdasarkan persamaan 21 dan 25 laju infiltrasi untuk lima macam perubahan laju infiltrasi dibagi dalam tiga tahap: (i) tahap awal, dicirikan oleh penurunan laju infiltrasi yang tajam; (ii) tahap transisi, dicirikan oleh perubahan laju infiltrasi agak landai; dan (iii) tahap akhir, dicirikan oleh penurunan laju infiltrasi yang landai.

Laju infiltrasi pada setiap tahapan mempunyai kuantítas yang berbeda, bergantung pada probabilitas hujan.

Pada p yang sama laju infiltrasi berbanding terbalik dengan lama hujan.

Laju infiltrasi lebih kecil pada waktu hujan (t) yang lebih lama. Beberapa alasannya adalah sebagai berikut.

1. Pada awal hujan kelembaban tanah di sekitar zone perakaran masih di bawah jenuh. 


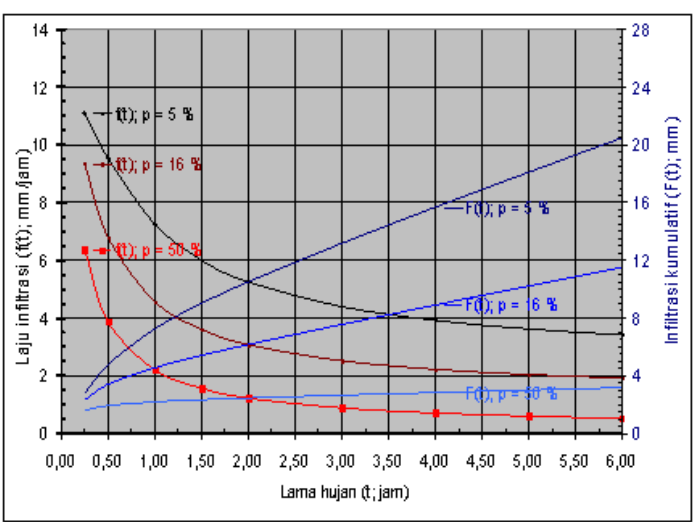

Sumber: Hasil Perhitungan

Gambar 7. Laju dan Kumulatif Infiltrasi pada Penggunaan Lahan Palawija

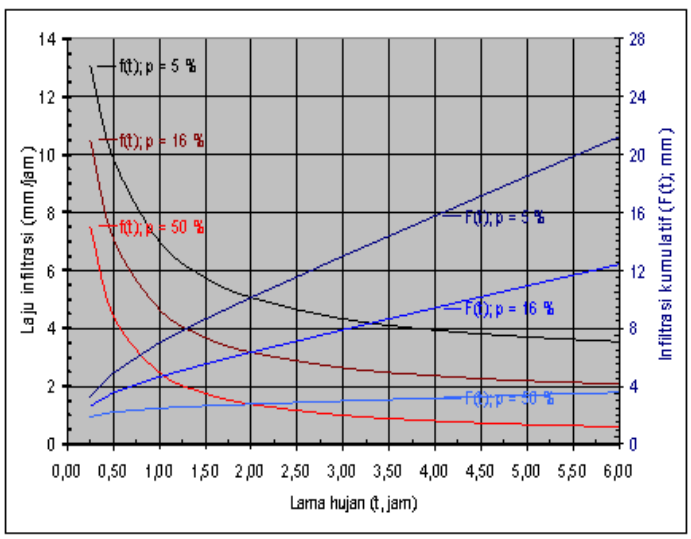

Sumber: Hasil Perhitungan

Gambar 8. Laju dan Kumulatif Infiltrasi pada Penggunaan Lahan Agroforestri

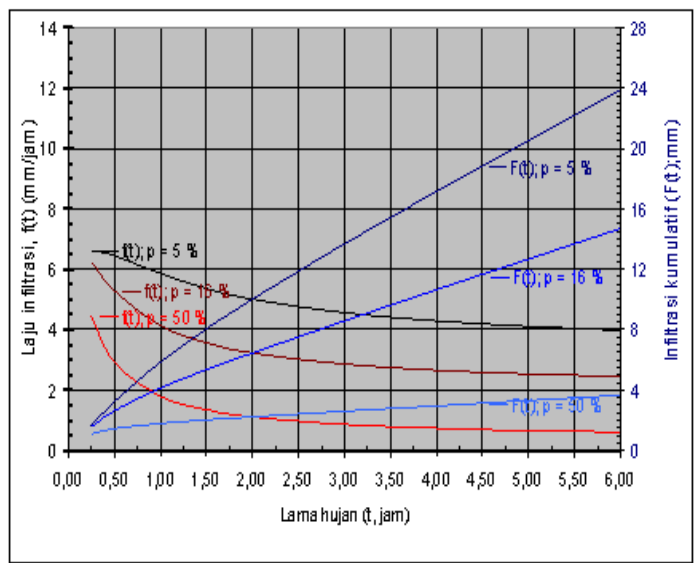

Sumber: Hasil Perhitungan

Gambar 9. Laju dan Kumulatif Infiltrasi pada Penggunaan Lahan Tidak Digarap

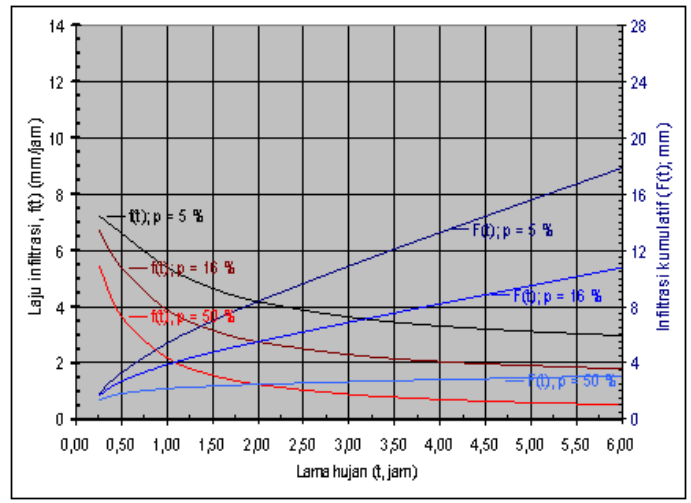

Sumber: Hasil Perhitungan

Gambar 10. Laju dan Kumulatif Infiltrasi pada Penggunaan Lahan Hutan

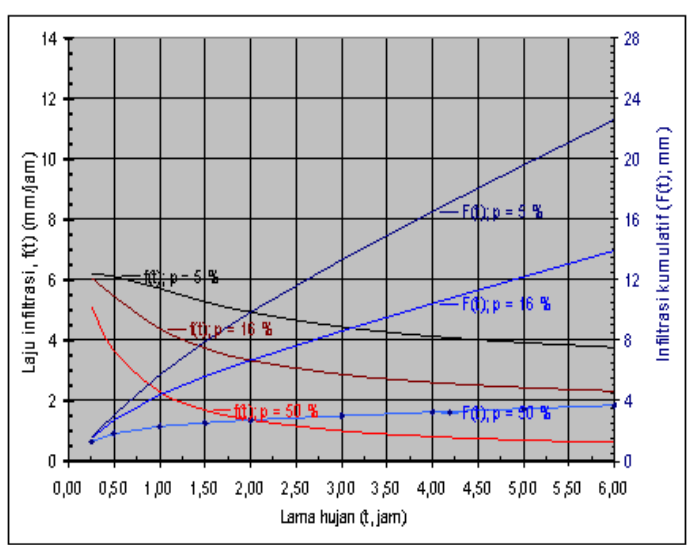

Sumber: Hasil Perhitungan

Gambar 11. Laju dan Kumulatif Infiltrasi pada Penggunaan Lahan Permukiman

2. Pertambahan kelembaban tanah pada zone perakaran menyebabkan berkurangnya nilai suction head dan menurunnya daya tampung tanah terhadap air infiltrasi.

3. Penyumbatan pori-pori di permukaan tanah oleh partikelpartikel tanah halus hasil pemecahan agregat tanah oleh percikan air hujan (erosi percik atau splash erosion), juga berperan dalam mengurangi laja infiltrasi. 
4. Jika zone perakaran jenuh, laju infiltrasi ditentukan oleh laju perkolasi pada zone transmisi. Laju perkolasi sangat ditentukan oleh kondisi kandungan air dan porositas front pembasahan.

Sejalan dengan lajunya, infiltrasi kumulatif $(\mathrm{F}(\mathrm{t}) \mathrm{m})$ pada $\mathrm{t}$ yang sama semakin besar dengan semakin kecilnya probabilitas hujan. Sebaliknya pada p yang sama, infiltrasi kumulatif semakin besar pada durasi hujan yang lama.

\section{f. Perbandingan Infiltrasi Kumulatif pada Setiap Macam Penggunaan Lahan}

Perbandingan dilakukan untuk setiap macam penggunaan lahan menurut probabilitas hujan 50, 16, dan $5 \%$ (Gambar 12, 13, dan 14). Pada $p=50 \%$ (Gambar 12), efek genangan permukaan pada lahan permukiman cukup efektif menambah infiltrasi kumulatif setelah hujan 3 jam. Infiltrasi pada lahan ini lebih besar daripada empat penggunaan lahan lainnya.

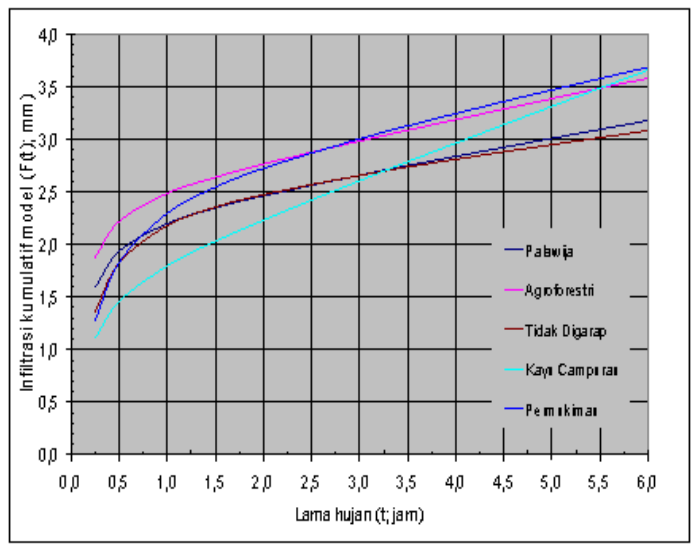

Sumber: Hasil Perhitungan

Gambar 12. Infiltrasi Kumulatif pada $p=50 \%$
Pada lahan hutan, sejak awal hujan $\mathrm{F}(\mathrm{t}) \mathrm{m}$ lebih kecil dari empat macam penggunaan lahan lainnya. Namun ketika $\mathrm{t}>3$ jam, $\mathrm{F}(\mathrm{t}) \mathrm{m}$ menjadi lebih besar daripada lahan tidak digarap dan palawija, dan pada $\mathrm{t}=6 \mathrm{jam}, \mathrm{F}(\mathrm{t}) \mathrm{m}$ hutan relatif sama dengan lahan agroforestri dan permukiman.

Hujan pada lahan permukiman, hampir seluruhnya jatuh dan diterima oleh permukaan tanah, sedangkan hujan $\mathrm{t}<3$ jam pada lahan agroforestri sebagian tertahan oleh tajuk tanaman.

Pada lahan hutan, sampai dengan $\mathrm{R}(\mathrm{t})$ tertentu, air hujan tertahan oleh tajuk tanaman. Seluruh air hujan diterima oleh tanah, ketika kapasitas tampung tajuk telah terpenuhi. Kondisi ini dicapai setelah beberapa jam hujan, tergantung ketebalan hujan. Terdapat dua fungsi utama tajuk tanaman dalam memperbesar $\mathrm{F}(\mathrm{t}) \mathrm{m}$ yaitu:

1. Menerima dan menampung sebagian air hujan, sehingga butir hujan tidak langsung jatuh di permukaan tanah.

2. Mengendalikan dan mengubah mekanisme penyaluran air hujan sebelum diterima oleh permukaan tanah.

Atas dasar fungsi tersebut, permukaan tanah menerima air hujan dalam bentuk air hujan yang jatuh dari tajuk tumbuhan dan melalui aliran batang, sehingga suplai air hujan lebih kontinyu dan lebih terkendali.

Pada lahan tidak digarap, $\mathrm{F}(\mathrm{t}) \mathrm{m}$ pada $\mathrm{t}=0,25-0,5$ jam lebih kecil daripada lahan palawija, namun kemudian meningkat. Hal ini menunjukkan bahwa intersepsi hujan oleh semak dan alangalang, efektif pada t 0,5 jam. Semak, alangalang dan serasah di permukaan lahan 
tidak digarap cukup efektif membantu proses infiltrasi, walaupun efektivitasnya masih lebih rendah dibandingkan dengan efek genangan di permukaan pada lahan permukiman, dan efek intersepsi pada hutan dan agroforestri.

$$
\text { Pada } p=16 \% \text { (Gambar 13), F(t) }
$$
terbesar terdapat pada lahan permukiman dan kayu campuran, yang dicapai pada $t$ $>1,5$ jam, sedangkan pada $t<1,5$ jam, $\mathrm{F}(\mathrm{t}) \mathrm{m}$ terbesar terdapat pada lahan agroforestri. Namun pada $\mathrm{t}>3 \mathrm{jam}, \mathrm{F}(\mathrm{t}) \mathrm{m}$ hutan menjadi terbesar.

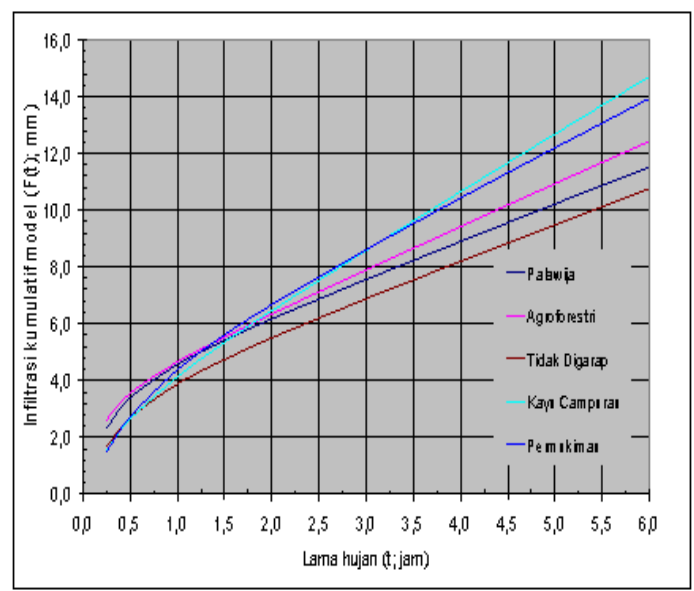

Sumber: Hasil Perhitungan

Gambar 13. Infiltrasi Kumulatif pada $p=16 \%$

Pada R(t) yang kecil (saat awal hujan), intersepsi masih cukup efektif untuk menahan air hujan. Namun dengan bertambahnya $t$ dan $R(t)$, kapasitas intersepsi akan terpenuhi secara optimal. Pada kondisi ini, suplai air hujan ke permukaan tanah sama dengan ketebalan hujan, dengan efektivitas yang lebih baik.

Pada $\mathrm{t}<3$ jam, $\mathrm{F}(\mathrm{t}) \mathrm{m}$ pada hutan dan lahan permukiman relatif sama, namun pada $t>3$ jam $F(t) m$ pada lahan permukiman menjadi lebih kecil. Di lain pihak, sejak awal hujan, $\mathrm{F}(\mathrm{t})_{\mathrm{m}}$ lahan palawija lebih besar dibandingkan dengan lahan tidak digarap. Tanaman semusim dan pengolahan lahan palawija memberikan efek positif pada pertambahan $\mathrm{F}(\mathrm{t}) \mathrm{m}$.

$$
\text { Pada } p=5 \% \text { (Gambar 14), F(t) }
$$
terbesar ( $>2$ jam) terdapat pada hutan dan permukiman. Padahal pada $t<2$ jam, $\mathrm{F}(\mathrm{t}) \mathrm{m}$ pada kedua lahan ini lebih kecil daripada lahan palawija dan agroforestri. Efek pengendalian air hujan oleh tajuk tanaman pada lahan hutan dan efek genangan permukaan pada lahan permukiman, efektif meningkatkan $\mathrm{F}(\mathrm{t}) \mathrm{m}$ pada $t>2$ jam.

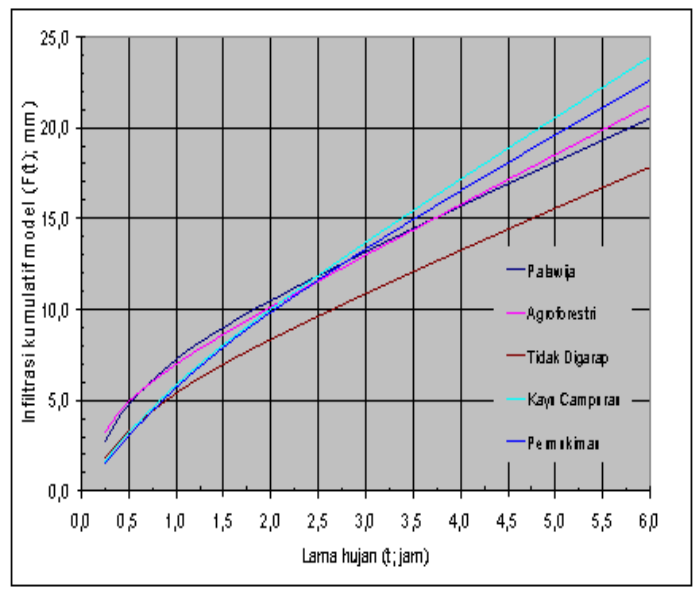

Sumber: Hasil Perhitungan

Gambar 14. Infiltrasi Kumulatif pada $p=5 \%$

Fenomena ekstrim terdapat lahan tidak digarap. Pada $t<0,5$ jam, $F(t) m$ lahan ini sama atau relatif lebih besar daripada lahan hutan dan permukiman. Namun pada $\mathrm{t}>0,5$ jam menjadi yang terkecil. Pertambahan infiltrasi kumulatif akibat pertambahan ketebalan hujan pada lahan 
ini, tidak setajam empat penggunaan lahan lainnya. Hal ini menunjukkan bahwa semak dan belukar yang menutupi lahan tidak digarap, hanya efektif mengendalikan hujan sampai dengan $\mathrm{t}=0,5 \mathrm{jam}$. Selebihnya, infiltrasi kumulatif relatif kecil dan air hujan dialirkan dalam bentuk aliran permukaan.

\section{Validitas Kuantitas Infiltrasi}

Validitas kuantitas infiltrasi hasil pendugaan $(\mathrm{F}(\mathrm{t}) \mathrm{m})$ untuk setiap macam penggunaan lahan, diketahui manakala dibandingkan dengan nilai infiltrasi empiriknya $\left(\mathrm{F}(\mathrm{t})_{\mathrm{C}_{\mathrm{r}}}\right)$ yang diekspresaikan oleh persamaan (24). Kedekatan antara kedua nilai $\mathrm{F}(\mathrm{t})$ tersebut, ditentukan oleh nilai korelasi.

Pada lahan palawija, nilai $\mathrm{F}(\mathrm{t}) \mathrm{m}$ sangat dekat dengan $\mathrm{F}(\mathrm{t})_{\mathrm{w}}$. Angka korelasi $\mathrm{p}=$ $50 \%$ sebesar 0,$95 ; \quad p=16 \% \quad 0,98$; dan pada $\mathrm{p}=5 \% \quad 0,99$. Simpangan rata-rata sekitar 10,89\%; simpangan terbesar terdapat pada $\mathrm{p}=16 \%$ yaitu $12,49 \%$; dan pada $\mathrm{p}=5 \% \quad 11,89 \%$; sedangkan terkecil pada $\mathrm{p}=50 \%$ sekitar $8,29 \%$.

Pada lahan agroforestri, nilai korelasi antara $\mathrm{F}(\mathrm{t}) \mathrm{m}$ dengan $\mathrm{F}(\mathrm{t})_{\mathrm{A}}$ pada p $50 \%$, $16 \%$, dan 5\%, masing-masing $0,96,0,99$; dan 0,99 . Rata-rata perbedaan antara $\mathrm{F}(\mathrm{t}) \mathrm{m}$ dengan $\mathrm{F}(\mathrm{t})_{\mathrm{A}}$ sebesar $8,63 \%$. Persentase perbedaan tertinggi, terdapat pada $\mathrm{p}=16 \%$ yaitu $9,885 \%$; terendah $7,97 \%$ pada $\mathrm{p}=5$ $\%$, dan $8,05 \%$ untuk $\mathrm{p}=50 \%$.

Pada lahan tidak digarap, nilai korelasi untuk $\mathrm{p}=50 \% ; 16 \%$; dan 5\%, masingmasing 0,90; 0,98; dan 0,99. Perbedaan rata-rata sekitar 10,99\%. Perbedaan tertinggi terdapat pada $\mathrm{p}=5 \%$, yaitu $12,54 \%$, sedangkan untuk $\mathrm{p}=16 \% 11,45$; dan $8,95 \%$ untuk $\mathrm{p}=50 \%$.

Pada laban butan, Pada setiap probabilitas, nilai korelasi $\mathrm{F}(\mathrm{t}) \mathrm{m}$ dengan $\mathrm{F}(\mathrm{t})_{\mathrm{H}}$, hampir mendekati sempurna. Nilai korelasi untuk $\mathrm{p}=50 \% ; 16 \%$; dan $5 \%$ berturut-turut sebesar 0,98; 0,99; dan 0,99. Simpangan rata-rata sekitar 11,16\%. Pada $\mathrm{p}=50 \%$, simpangan sekitar $6,94 \% ; \mathrm{p}=$ $16 \%$ dan $p=5 \%$ masing-masing 11,60 dan $14,93 \%$.

Pada lahan permukiman, nilai korelasi untuk $\mathrm{p}=50 \%$ sebesar 0,$93 ; \mathrm{p}=16 \%$ 0,98 ; dan $p=5 \% 0,99$. Simpangan ratarata sekitar $12,30 \%$. Simpangan tertinggi pada $\mathrm{p}=5 \%$ yaitu $14,74 \%$, sedangkan terendah pada $\mathrm{p}=50 \%$ yaitu $8,82 \%$; dan pada $\mathrm{p}=16 \%$ sebesar $13,34 \%$.

\section{KESIMPULAN DAN REKOMENDASI}

\section{Kesimpulan}

1. Pola intensitas hujan $\left(\mathrm{I}_{\mathrm{t}, \mathrm{p}}\right)$ di wilayah penelitian diformulasikan sebagai fungsi dari lama hujan (t; jam) dan probabilitas kejadian hujan ( $\mathrm{p} ; \%)$.

$$
I_{t, p}=\left(\frac{9,16+6,61 \cdot t}{t}\right) \cdot e^{-k}
$$

dengan $e=2,718 ;$ dan $\mathrm{k}=0,0375 . \mathrm{p}$

2. Tipikal laju infiltrasi untuk masingmasing macam penggunaan lahan $\left(\mathrm{f}(\mathrm{t})_{\mathrm{Cr}} ; \mathrm{mm} / \mathrm{jam}\right)$, diprediksi oleh:

$$
f(t)_{C r}=10 \cdot e^{a}\left[\frac{\mu}{\chi_{C r}}+1\right]
$$

dimana: 


$$
\begin{aligned}
\mathrm{a}= & -2.391-0.090 \mathrm{q}+0,161 \mathrm{~h}_{\mathrm{c}}+ \\
& 0,845 \mathrm{~h}_{\mathrm{l}} ; \\
\eta= & \left(-10^{\mathrm{pF}} \cdot \mathrm{Dq}\right) ; \\
\mathrm{pF}= & 29,30-1,684 \theta+0371 \theta^{2}- \\
& 0,00029 \theta^{3} ; \\
\Delta \theta= & (\eta-\theta) ; \text { dan }
\end{aligned}
$$

$\chi_{\mathrm{Cr}}$ adalah :

$$
\chi_{W}=\frac{69.36}{p^{0.091}} e^{\frac{1.99}{t} p^{-0.59}}
$$$$
\chi_{A}=\frac{95.93}{p^{0.077}} e^{\frac{0.77}{t} p^{-0.40}} ;
$$$$
\chi_{N}=\frac{59.48}{p^{0.148}} e^{\frac{2.03}{t} p^{-0.46}} ;
$$$$
\chi_{H}=\frac{61.58}{p^{0.268}} e^{\frac{4.95}{t} p^{-0.75}} ; \text { dan }
$$

$$
\chi_{P}=\frac{57.46}{p^{0.251}} e^{\frac{5.72}{t} p^{-0.66}}
$$

$\mathrm{f}(\mathrm{t})_{\mathrm{Cr}}$ merupakan rata-rata selama kurun waktu satu kejadian hujan. Infiltrasi kumulatif diformulasikan sebagai: $F(t)_{C r}=f(t)_{C r}$. $t$.

3. Laju infiltrasi semakin rendah dengan bertambahnya waktu dan probabilitas hujan, sedangkan infiltrasi kumulatif semakin besar dengan bertambahnya waktu hujan dan semakin kecilnya probabilitas hujan.

4. Pada kejadian hujan yang singkat dan kecil di atas lahan bertajuk lebat (hutan), sebagian besar hujan tertahan oleh intersepsi, sehingga infiltrasi kumulatif untuk sangat kecil.
Infiltrasi kumulatif pada lahan hutan bertambah secara nyata dengan bertambahnya lama dan ketebalan hujan.

5. Hasil pendugaan infiltrasi, menunjukkan nilai yang cukup akurat dan mendekati nilai infiltrasi kumulatif empirik. Nilai korelasi dan simpangan rata-rata infiltrasi kumulatif pada lahan palawija masing-masing adalah 0,97 dan 10,89 $\%$, lahan agroforestri 0,98 dan 8,63 $\%$; lahan tidak digarap 0,95 dan $10,99 \%$; lahan kayu campuran 0,99 dan $11,16 \%$; dan permukiman 0,97 dan $12,30 \%$.

\section{Rekomendasi}

1. Tipikal kuantitas infiltrasi hasil kajian ini, dapat dikembangkan untuk wilayah lain, dengan memperhatikan karakteristik sebagai berikut :

- Kawasan DAS bagian tengah dan hulu yang mempunyai curah hujan tinggi.

- Morfologi DAS berombak atau lebih terjal

- Tanah mempunyai tekstur clay (lempung) hingga clay loam; kandungan pasir sekitar $10 \%$, serta kandungan silt dan clay sekitar $90 \%$ dengan komposisi relatif berimbang.

2. Diperlukan penelitian lanjutan untuk lebih mempertajam akurasi dan mengembangkan hasil penelitian ini ke kawasan satuan hidrologi yang lebih luas dan lebih variatif sifat fisik tanah dan morfologi lahannya. 


\section{DAFTAR PUSTAKA}

Chow, V.T., Maidment, D.R., and Mays L.W. 1988. Applied Hydrology, McGraw-Hill Book Company, New York, St. Louis, etc; 110-113.

Darmawan, I. 1998. Kajian Laju Infiltrasi Berdasarkan Jenis Batuan dan Data Sifat Fisik Tanah (Studi Kasus: Kawasan Bandung Utara dan Wilayah Jakarta); Tesis Magister. Bidang Khusus Hidrogeologi, Program Studi Rekayasa Pertambangan, Program Pasca Sarjana - ITB.

Darmawidjaja, Isa. 1990. Klasifikasi Tanah, Dasar Teori Bagi Peneliti Tanah dan Pelaksana Pertanian di Indonesia, Gadjah Mada University Press. Yogyakarta; 295-319.

Jia, Y. and Tamai, N. 1998. Modeling Infiltration Into Multi-Layered Soil During an Unsteady Rain. Journal Of Hydroscience And Hydraulic Engineering, Vol.16, No. 2, November-1998;110.

Koorevaar, P., G. Menelik and C. Dirksen.1983. Elements of Soil Physics. Depart. of Soil Science and Plant Nutrition, Agricultural University of Wageningen, The Netherlands, Alsevier, Amsterdam, Oxford, New York, Tokyo: $9-10$.

Laat, P.J.M. de. 1987. Agricultural Hydrology, International Institute for Hydraulic and Environmental Engineering, Delft Netherlands; 39 - 40.

Pramono Hadi, M. 2006. Pemahaman Karakteristik Hujan sebagai Dasar Pemilihan Model Hidrologi (Studi Kasus di DAS Bengawan Solo Hulu), Jurnal Forum Geografi Vol. 20, No. 1, Juli 2006.

Purwanto, E. 1999. Erosion, Sediment Delivery and Soil Conservation in an Upland Agricultural Catchment in West Java, Indonesia; A Hydrological Approach in A Socio-Economic Context. Academisch Proefschrift, Vrije Universeteit te Amsterdam.

Pusat Penelitian Tanah dan Agroklimat. 1997. Statistik Sumber Daya Laban/Tanab Indonesia, Badan Penelitian dan Pengembangan Pertanianm, Departemen Pertanian: 29.

Rohmat Dede dan Indratmo Soekarno. 2004. Pendugaan Limpasan Hujan pada Cekungan Kecil melalui Pengembangan Persamaan Infiltrasi Kolom Tanah (Kasus di Cekungan Kecil Cikumutuk Das Cimanuk Hulu); Makalah PIT HATHI XXI, September-Oktober 2004, DenpasarBali.

Soil Survey Staff USDA. 1975. Soil Taxonomy, A Basic System of Soil Classification for Making and Interpreting Soil Survey. Soil Conserv. Service USDA, Agric. Handbook No. 436. 


\section{Lampiran 1. Notasi}

$\Delta \theta \quad$ Pertambahan kelembaban tanah dari kondisi awal hingga sama dengan nilai porositas.

$f(t) \quad$ Laju infiltrasi akhir

$\mathrm{F}(\mathrm{t})_{\mathrm{Cr}}$ Infiltrasi kumulatif empirik tipikal pada lima macam penggunaan lahan

$\mathrm{F}(\mathrm{t})_{\mathrm{W}} \quad$ Infiltrasi kumulatif empirik lahan palawija

$\mathrm{F}(\mathrm{t})_{\mathrm{A}} \quad$ Infiltrasi kumulatif empirik lahan agroforestri

$\mathrm{F}(\mathrm{t})_{\mathrm{N}} \quad$ Infiltrasi kumulatif empirik lahan tidak diagarap

$\mathrm{F}(\mathrm{t})_{\mathrm{H}} \quad$ Infiltrasi kumulatif empirik lahan hutan

$\mathrm{F}(\mathrm{t})_{\mathrm{p}} \quad$ Infiltrasi kumulatif empirik lahan permukiman

$\mathrm{F}(\mathrm{t}) \mathrm{m}$ Infiltrasi kumulatif hasil pendugaan untuk lima penggunaan lahan

h Penjumlahan suction head $(\mathrm{Y})$ dan gravity head $(\mathrm{z})$

$\mathrm{h}_{1} \quad$ Head permukaan sama dengan kedalaman genangan (ho)

$\mathrm{h}_{2} \quad$ Head tanah yang kering di bawah wetting front

$\mathrm{I}_{\mathrm{t}, \mathrm{p}} \quad$ Pola intensitas hujan sebagai fungsi t dan $\mathrm{p}(\mathrm{mm} / \mathrm{jam})$

K Pemeabilitas

L Kedalaman kolom tanah dari permukaan

$\eta \quad$ Porositas total

$\eta_{c} \quad$ Pori drainase cepat

$\eta_{1} \quad$ Pori drainase lambat

$\mathrm{o}_{\mathrm{m}} \quad$ Bahan organik

p Probabilitas hujan (\%)

pF Potential free energy

$\psi \quad$ Suction head

q Darcy flux

$\rho_{\mathrm{b}} \quad$ Berat jenis tanah (bulk density)

$\rho_{\mathrm{p}} \quad$ Kerapatan jenis butir tanah (partikel density)

$\mathrm{R}(\mathrm{t})_{\mathrm{t}, \mathrm{p}} \quad$ Ketebalan hujan sebagai fungsi dari t dan $\mathrm{p}$

$\mathrm{s}_{\mathrm{c}} \quad$ Coarse sand (pasir kasar)

$\mathrm{s}_{\mathrm{f}} \quad$ Fine sand (pasir halus)

$\mathrm{s}_{\mathrm{i}} \quad$ Lanau (silt)

t Durasi hujan

$\theta \quad$ Kandungan air (Volumetric Water Content)

z Gravity head 